\title{
An Improved Method to Generate Electricity and Precipitated Silica from Rice Husk: Perspective Bangladesh
}

\author{
Arif Md. Waliullah Bhuiyan, Md. Rejwanur Rashid Mojumdar and A K M Kamrul Hasan
}

\begin{abstract}
Electricity supply for rural areas, so long, has been a far cry in context of Bangladesh. Realizing this, many organizations along with Bangladesh government are trying to bring renewable energy in a competitive package to meet deficiency. But solar energy, mainly for its inefficiency and high cost, is not having much success in a broader aspect. SHSs are capable to maintain only household demand for 4-6 hours. But for the emergence of small enterprises and to boost the rural economy, energy security at countryside has indispensible role. This paper explores rice husk based biomass plant as an alternate energy source to meet the electricity demand of local enterprises, irrigation and rural households. Since the availability of rice husk is at stake, a mixture of biomass (rice husk \& saw dust or rice husk \& bamboo dust) instead of using only rice husk as fuel is also proposed for electricity generation. Ash generated from the husk is processed to produce silica and calcium carbonate through silica precipitation method. Demand and market analysis is also done to examine sales potential of products (electricity, silica and calcium carbonate).
\end{abstract}

Index Terms-Biomass gasification, Electricity generation by rice husk, Silica By-product generation, Product utilization

\section{INTRODUCTION}

Expanding rural electrification is the key to the prosperity and development of rural areas as well as to fulfill Bangladesh Government's vision of ensuring access to affordable and reliable electricity for all by 2020. It is well recognized that energy demand in our rural areas is increasing and supply of fossil fuel at subsidized prices is becoming an unattainable challenge for the government. Moreover, providing power without intensifying the effect of climate change is also a priority for Bangladesh. Eventually, emphasis on increasing the energy conversion efficiency and promoting the use of alternate energy sources has been increased lately.

Approximate land use for agriculture is $54.5 \%$, while the forest covers $17.6 \%$ of total land area of the country. About $46 \%$ of traditional biomass energy is supplied from agricultural residues such as rice straw and rice husk from rice plants, bagasse from sugarcane and jute stick. Some amount of residues produce from wheat, potato, oilseeds, spices, etc. Crop residues can be distinguished into field

Manuscript received July 13, 2011, revised August 9, 2011.

Arif Md. Waliullah Bhuiyan is with the BRAC, Mohakhali, Dhaka,

Bangladesh. (e-mail: bhuiyan.waliullah@gmail.com).

Md. Rejwanur Rashid Mojumdar is now with HM Enviro Care, Dhaka-1000, Bangladesh.

(e-mail:md.rejwanur.rashid.mojumdar@gmail.com).

A K M Kamrul Hasan is with Islamic University of Technology, Dhaka, Bangladesh. (e-mail: kamrul_2075@yahoo.com )

Arif Md. Waliullah Bhuiyan and Md. Rejwanur Rashid Mojumdar both are members of IACSIT. residues and process residues where field residues are residues that are left in the field after harvesting and generally used as fertilizer. On the other hand, process residues are generated during crop processing, e.g. milling [1]. Between these two types, process residues are usually available at a central location that enables to collect raw materials efficiently.

Out of various biomass energy technologies, biomass gasification process is yet to get recognition in Bangladesh. Other neighboring Asian countries especially India and China have already undertaken gasification programs on large scale. On the other hand, only a demonstration biomass gasification of $200 \mathrm{~kW}$ based on rice husk is being set up by Local Government Engineering Department (LGED) at Dinajpur. The first commercial rice husk based power plant is established by a private entrepreneur in Kapasia, near Dhaka, with financial assistance from Infrastructure Development Company Limited (IDCOL).

\section{BIOMASS GASIFICATION}

Biomass gasification is the process of converting solid fuels (wood/ wood-waste, agricultural residues etc.) into a combustible gas mixture usually referred as producer gas or synthesis gas (syngas). The process involves partial combustion of such solid fuels that occurs when air supply $\left(\mathrm{O}_{2}\right)$ is less than adequate for the complete combustion of biomass. During partial combustion solid biomass fuels are broken in an oxygen-starved environment by the application of heat to produce a mixture of combustible gas which is called producer gas. Fuels that are conducive to biomass gasification include dry materials such as dry wood, dried leaf, charcoal, rice husks, coconut shells etc.

The main component of the biomass gasification system is primarily a reactor into which fuel/feed stock is fed with a limited (less than stoichiometric, that required for complete combustion) supply of air to craft chemical breakdown; eventually generate producer gas. The calorific value of this gas varies between 4.0 and $6.0 \mathrm{MJ} / \mathrm{Nm}^{3}$ or about 10 to 15 percent of the heating value of natural gas [2].

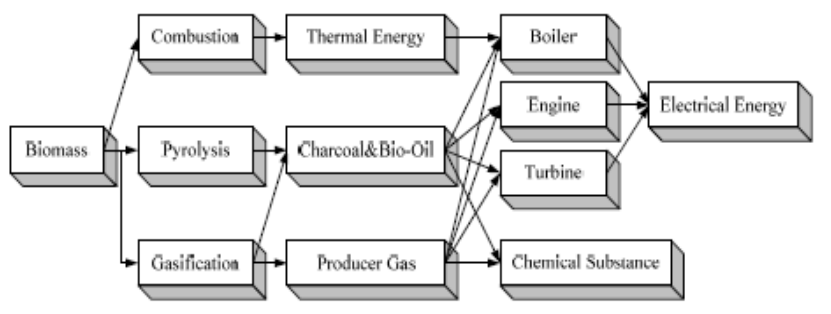

Fig. 1. Biomass conversion into energy [3]

The advantage of gasification technology is cost effectiveness and higher efficiency. In this process electrical 
and thermal energy can be generated simultaneously. Gasifiers offer a flexible option for thermal applications, as they can be fitted into existing gas fueled devices such as ovens, furnaces, boilers etc., where syngas may replace fossil fuels, lower the household demand for natural gas. Heating value of syngas is generally around $4-10 \mathrm{MJ} / \mathrm{m}^{3}[4]$.

\section{TREND OF BIOMASS ENERGY USE IN BANGLADESH}

Over last 30 years, there has been an increasing trend of biomass fuel supply in Bangladesh. The total supply of biomass fuel was 236.08 PJ in 1980 and has increased over next 20 years to 356.66 PJ (1.73\% growth). Traditional fuel supply usually comes from main three sources viz. crop residues, animal dung and trees [5].

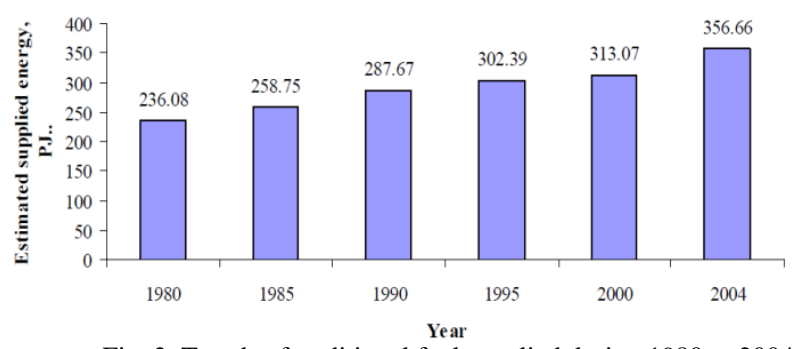

Fig. 2. Trends of traditional fuel supplied during 1980 to 2004

The percentages of different traditional energy were as follows: cow-dung $20.4 \%$, jute stick $7.5 \%$, rice straw $11.6 \%$, rice husk $23.3 \%$, bagasse $3.2 \%$, fire wood $10.4 \%$, twigs and leaves $12.5 \%$ and other wastes $11.1 \%$. Rice husk contributes biggest share of biomass energy and it was 83.04 PJ in 2003-2004. Energy production from rice husk is steadily increasing. In 1991, the production of rice husk energy was 76.35 PJ and it increased to 106.1 PJ in 2004 (Figure 2) [5].

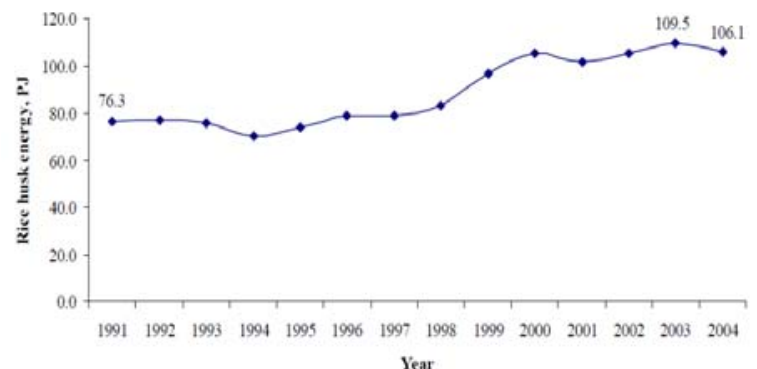

Fig. 3. Trends of rice husk energy production during last decade in Bangladesh [5]

\section{RiCE HUSK CLUSTERS IN BANGLADESH}

About 4 - 4.5 million metric tons (MT) of paddy is annually produced in the Bangladesh. A 20\% yield of input paddy leads to a production of 8 - 9,000,000 metric tons rice husk annually. Using biomass gasifier technology and considering that about half of the husk is used for energy applications such as domestic cooking, steam production for rice parboiling etc., the theoretical potential (TP) of the remaining half i.e. 4 million MT / year of husk, is estimated at a little over about 400 MW of capacity.

According to the Rice Mill Owners' Association of Bangladesh there are over one hundred thousand rice mills located in a scattered manner all over the country with four 'cluster' areas. Over ninety percent of these rice mills are reported to be in smaller capacity ranges, i.e. $<20-25$
MT/day of paddy processing capacity. The number of lower-midsized rice mills (with paddy processing capacity range : > 25 - $50 \mathrm{MT} /$ day) are reported to be about 490 and that of mid to large sized rice mills (30- $120 \mathrm{MT} /$ day) are about 50 units. These four distinct 'cluster' areas are distinguished as - (i) Dinajpur (North Bengal) (ii) Sherpur (near Bogra) (iii) Inshawerdi and (iv) Kaliakoir (near Dhaka), where most of the rice mills are located in close proximity to each other.

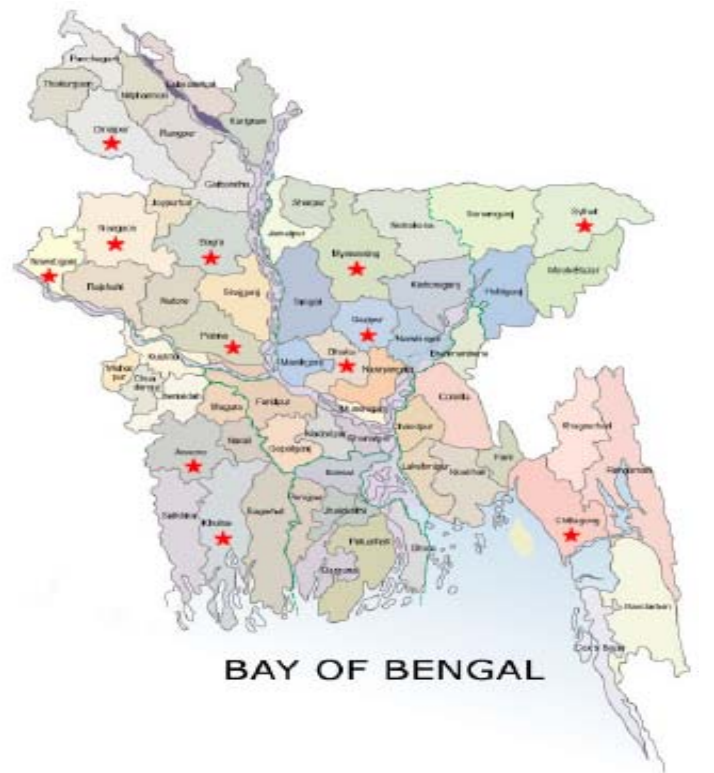

Fig. 4. Districts with rice mill clusters (red marked) in Bangladesh [6]

IDCOL already financed two such projects in Kapasia, near Dhaka and recently one in Thakurgaon sadar, Thakurgaon. Hence, based on preliminary surveys (Ref.: Bangladesh Rice Research Institute, BRRI and information from Rice Mill Owners' Association), typically at least over 500 rice mills are located in these cluster areas. Taking an average (lower-mid) capacity range of about 100-200 kW, there is a 50-100 MW power market in these cluster areas [7].

Areas like Dinajpur, Sherpur etc are having intermittent power supply which often leads to less production for these rice mills and also other energy craving small enterprises and local dwellers are potential consumers for future rice husk based biomass power plant.

\section{EleCtricity GENERATION By Rice Husk GASIFICATION}

Gasification is the conversion of biomass to a gaseous fuel by heating in a gasification medium such as air, oxygen or steam. Unlike combustion where oxidation is substantially complete in one process, gasification converts the intrinsic chemical energy of the carbon in the biomass into a combustible gas in two stages [3]. If biomass is gasified efficiently, it can generate a high amount of clean product gas. The initial step to the process is a thermo-chemical decomposition of lignocellulosic compounds where char, tar and volatile compounds produce as output.

By thermo-chemical gasification solid fuel is transformed into gaseous fuel. Through this process, the chemical energy of solid fuel is converted into both thermal and chemical energy. The chemical energy contained depends on its chemical composition that determines the quality of product gas. High concentration of combustible gases like $\mathrm{H}_{2}, \mathrm{CO}$ and $\mathrm{CH}_{4}$ increase the combustion energy of the product gas. 
Several types of gasifiers e.g. fixed-bed updraft and downdraft gasifier, fluidized bed gasifier and bubbling bed gasifier are available in the existing market with different sets of pros and cons. However, the downdraft gasifier is a comparatively cheap and the gasification in this type of gasifier can produce a product gas with very low tar content [3]. Keeping the process in mind, fixed-bed downdraft gasifier is thus recommended for small-scale rice husk biomass plant. Here, biomass fuel is fed at the top of the reactor/gasifier. The fuel then slowly moves down and during this time, the fuel reacts with air (the gasification agent), which is supplied by the suction of a blower or an engine and is converted into combustible producer gas in a complex series of oxidation, reduction, and pyrolysis reactions [2]. Generated ash is then removed from the bottom of the reactor for silica production.

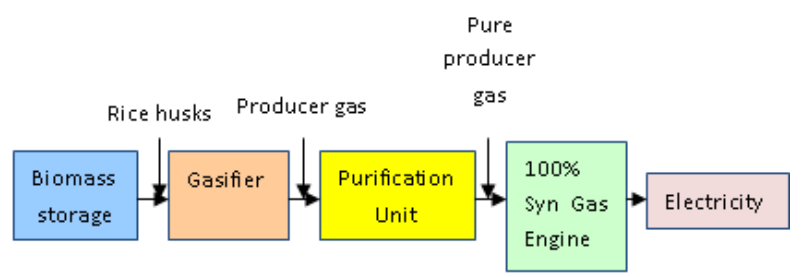

Fig. 5. Electricity generation by rice husk gasification

\section{A. Downdraft Gasification}

In a downdraft or co-current gasifier both gas and solid flows in the same downward direction. An elaborate schematic view of downdraft gasifier is shown in figure 6 . Biomass enters the system from the top of the unit and is converted into gas as it descends. While the rice husk/biomass progresses down through the reactor it dries, devolatilizes and combusts.

As seen in the co-current model in figure 6, the gas leaving the devolatilization region, and therefore rich in tar is forced to pass through the combustion region where a bed of hot charcoal exists. Most of the primary tar (consisting of oxygenated organic compounds) formed during pyrolysis is cracked and burnt in a process called flaming pyrolysis [8]. The flame temperatures are in the range of between $1273 \mathrm{~K}$ and $1673 \mathrm{~K}$, but the flame occurs in the interstices of the pyrolysing particles which have temperatures between $773 \mathrm{~K}$ and $973 \mathrm{~K}$. About $0.1 \%$ of the primary tars are converted to secondary tars and the rest are burned to supply the energy for pyrolysis and char gasification [8].

Downdraft gasification produces secondary tars whereas tars produced by updraft gasifiers are primary tars. Therefore, the produced gas is cleaner than the equivalent provided by the countercurrent model. The co-current version presents some limitations on controllability for large diameters or power output $[9,10]$.This is mostly due to the formation of preferential channels in the fuel bed that prevent the tar rich stream moving from the pyrolysis region from meeting the hot core of the combustion region. Nevertheless, that problem is mitigated through the application of slow-rotating paddles to provide uniform distribution of particles in the bed [11].

Although there has been some limitations of downdraft gasification, but in the proposed system the effect is not severe. There are high amounts of ash and dust particles in the gas due to the fact that the gas has to pass the oxidation zone where it collects small ash particles. The high ash content generated by the combustion is not considered a drawback as the generated ash would be reused to produce silica by precipitation process.

The moisture content of the biomass has to be carefully monitored as on wet basis moisture content must be less than $25 \%$ by mass [12]. The relative high temperature of the leaving flue gases result in lower gasification efficiency because these gases do not exchange heat with the wet biomass to be gasified [11].

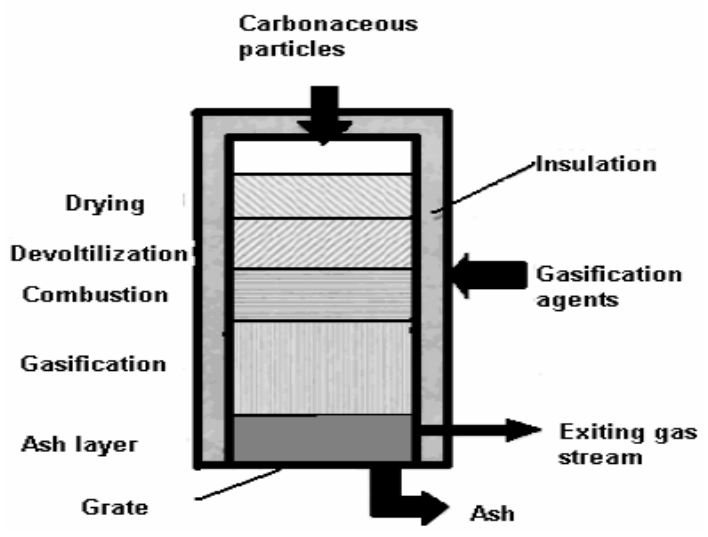

Fig. 6. Schematic of downdraft gasifier

A gasifier model is proposed below in table I:

TABLE I: FEATURES OF A PROPOSED GASIFIER (MODEL OI-405RHP)

\begin{tabular}{ll}
\hline \hline Particulars & Model OI - 405RHP \\
\hline Biomass consumption & $1.6-1.8 \mathrm{~kg} / \mathrm{kWh}$ \\
Gas heat value & $4500-5500 \mathrm{~kJ} / \mathrm{m}^{3}$ \\
Gas capacity (maximum) & $1200 \mathrm{~m}^{3} / \mathrm{hr}$ \\
TAR content & $<50 \mathrm{mg} / \mathrm{m}^{3}$ \\
Gasification efficiency & $>70 \%$ \\
Self consumed elec. Power & $20-40 \mathrm{~kW}$ \\
Water consumption (replace & $<0.5 \mathrm{Liter} / \mathrm{kWh}$ \\
evaporation) & \\
\hline \hline
\end{tabular}

\section{B. Generator}

The generators that could be used for the proposed scheme are synchronized, three-phase, turbocharged and water cooled V series open chamber combustion type. They are designed to operate together with reciprocating engines and run by $100 \%$ syngas. In table II, a recommended generator with specification is given.

TABLE II: FEATURES OF A PROPOSED GENERATOR (CUMMINS GTA-1710-G)

\begin{tabular}{ll}
\hline \hline Particulars & Cummins GTA-1710-G \\
\hline Rated power of generator & $358 \mathrm{KW}$ \\
Driving power & $1040 \mathrm{KW}$ \\
Nominal voltage & $415 \mathrm{~V}$ \\
Frequency & $50 \mathrm{~Hz}$ \\
Speed & $1500 \mathrm{rpm}$ \\
Power factor & $0.8 \mathrm{lag}$
\end{tabular}

\section{Mixing of Biomasses in case of availability constraint}

In Bangladesh, rise husk is mainly used for preparing briquette fuel as an alternative to wood fuel. The briquette fuel is dry woody material with calorific value ranging from 14.2 to $17.5 \mathrm{MJ} / \mathrm{kg}$ and equivalent to " $\mathrm{B}$ ” grade coal in terms of calorific value [13]. Now, as the major portion of rice husk is being consumed for briquette preparation and moreover, husk is only abundant during the crop seasons, availability of sufficient husk for electricity generation throughout the year will be a well raised question. Buragohain et. al [14] gives a 
better solution to the problem by proposing mixture of available biomasses instead of single biomass as input. So when rise husk is not available as per required electricity generation, other potential biomass e.g saw dust, bamboo dust, coconut shell etc. can be added with rice husk to certain proportions.

TABLE III: BIOMASS MiXTURES (BASIS: 100G OF TOTAL BIOMASS

\begin{tabular}{|c|c|c|c|}
\hline \multirow{2}{*}{$\begin{array}{c}\text { Biomass } \\
\text { components }\end{array}$} & \multirow{2}{*}{$\begin{array}{l}\text { Mixture } \\
\text { compositions }\end{array}$} & \multicolumn{2}{|c|}{$\begin{array}{l}\text { Net Energy Content (kJ per } \\
100 \mathrm{~g})\end{array}$} \\
\hline & & Ref.[15] & Ref.[16] \\
\hline $\begin{array}{l}\text { Rice Husk } \\
\text { (RH) }\end{array}$ & $\begin{array}{l}\mathrm{RH}=75 \% \\
\mathrm{SD}=25 \%\end{array}$ & 1590 & 1649 \\
\hline $\begin{array}{c}\text { Saw Dust } \\
\text { (SW) }\end{array}$ & $\begin{array}{l}\mathrm{RH}=50 \% \\
\mathrm{SD}=50 \%\end{array}$ & 1729 & 1785 \\
\hline $\begin{array}{l}\text { Rice Husk } \\
\text { (RH) }\end{array}$ & $\begin{array}{l}\mathrm{RH}=75 \% \\
\mathrm{BU}=25 \%\end{array}$ & 1468 & 1537 \\
\hline $\begin{array}{c}\text { Bamboo } \\
\text { Dust (BU) }\end{array}$ & $\begin{array}{l}\mathrm{RH}=50 \% \\
\mathrm{BU}=50 \%\end{array}$ & 1485 & 1560 \\
\hline
\end{tabular}

The above mentioned table is derived from [14], showing four different bi-mixtures of rice husk either with saw dust or bamboo dust keeping higher proportion of rice husk. Net energy content in biomass mixture, depending on the second biomass type e.g saw dust or bamboo, can vary. Moreover, [14] shows that mixture with other biomass i.e saw dust with rice husk increases the $\mathrm{CO}$ content significantly then the single biomass (rice husk) only. Although mixing bamboo with rice husk would result in lesser production of producer gas thus less electricity generation. But for the sake of continue electricity generation, during the scarce season, mixing with saw dust or bamboo dust could be a rational solution. Moreover, silica content in rice husk ash is way higher than other two types of ashes, resulting in low yield of silica when proportion of rice husk in the biomass mixture is reduced.

\section{Precipitated Silica Production}

$18 \%$ of the rice husk can be retrieved as ash after the gasification process. Silica content in ash is almost $90 \%$ and the rate of recovery of precipitated silica is $90-95 \%$ from the rice husk ash if the conversion efficiency is more than $70 \%$. Rice hull ash (RHA) contains over $60 \%$ of silica which can be an economically viable raw material for the production of silica based products [17].

TABLE IV: COMPOSITION OF RICE HUSK ASH ON DRY BASIS [18]

$\begin{array}{ll}\text { Element } & \text { Mass Fra } \\ \text { Silica }\left(\mathrm{SiO}_{2}\right) & 80-90 \% \\ \text { Alumina } & 1-2.5 \% \\ \text { Ferric oxide } & 0.5 \% \\ \text { Calcium oxide } & 1-2 \% \\ \text { Magnesium oxide } & 0.5-2.0 \% \\ \text { Sodium oxide } & 0.2-0.5 \% \\ \text { Potash } & 0.2 \% \\ \text { Loss on ignition } & 10-20 \%\end{array}$

From Table IV, it is clear that silica is the major constituent of the rice husk ash. So precipitated silica production will not only provide value addition but also solve the problem of large amount of ash disposal generated from gasification process. Moreover, the silica industry in Bangladesh, entirely dependent upon import, will have another mean to cut their spending if initiatives like this are taken.

Silica generation is a separate independent process not dependent on electricity generation, although the input ash is dependent on gasification process. Provision will be taken in the design so that external ash is used also as input thus increase silica production. The process along with three major steps of production is depicted in below mentioned figure.

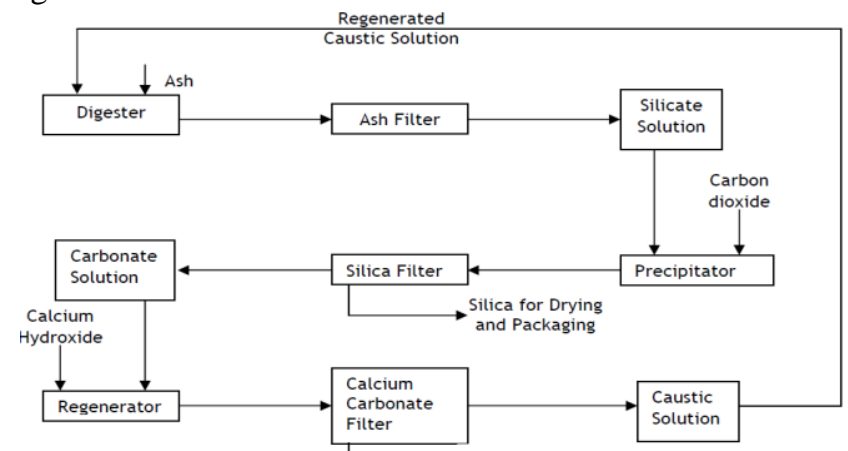

Fig. 7. Flow chart of precipitated Silica [18]

\section{A. Digestion}

This step involves the digestion of the rice husk ash with caustic to formulate sodium silicate solution at specific condition. After the digestion stage, the solution is filtered for residual undigested ash present in the solution. The clear filtrate is then taken for precipitation.

Ash $+\mathrm{NaOH}(\mathrm{l}) \rightarrow \mathrm{Na}_{2} \mathrm{O} \cdot \mathrm{xSiO} \mathrm{SiO}_{2}(\mathrm{l})+$ Undigested ash

\section{B. Precipitation}

This step involves precipitation of silica from sodium silicate solution in presence of Carbon-Di-Oxide. Continuous stirring is required during this operation. The precipitated silica is then filtered, washed with water to remove the soluble salts and dried to form silica powder. The filtrate containing sodium carbonate is taken for regeneration purpose [19].

$$
\mathrm{Na}_{2} \mathrm{O} \cdot \mathrm{xSiO} \mathrm{SiO}_{2}(\mathrm{l})+\mathrm{CO}_{2}(\mathrm{~g}) \rightarrow \mathrm{xSiO}_{2}(\mathrm{~s})+\mathrm{Na}_{2} \mathrm{CO}_{3}
$$

The quality of silica produced is determined in the precipitation stage. The surface area, the bulk density etc. are dependent on several process parameters such as concentration of the silicate solution taken for precipitation, temperature at which the precipitation is carried out, carbon dioxide flow rate and the duration of precipitation. The surface area is affected by the precipitation conditions like temperature, agitation etc with different initial concentrations of silica. These parameters also affect the bulk density of silica produced. Therefore, for obtaining a given set of these properties the conditions of precipitation should be carefully set [19].

\section{Regeneration}

The filtrate from the precipitation process contains sodium carbonate which is reacted with calcium compound to produce calcium carbonate. Regeneration is the step where calcium compound reacts with the sodium carbonate to form calcium carbonate and sodium hydroxide. The resulting solution is filtered to remove the solid calcium carbonate and the aqueous sodium hydroxide is used for digestion again. The calcium carbonate is washed with water and then dried. 
The dried calcium carbonate can be either calcined to get calcium oxide, which is reused, for regeneration or the calcium carbonate is sold and fresh calcium hydroxide is used for regeneration which gives an option of one more value addition [18].

$$
\begin{aligned}
& \mathrm{Na}_{2} \mathrm{CO}_{3}(\mathrm{l})+\mathrm{Ca}(\mathrm{OH})_{2}(\mathrm{~s}) \rightarrow \mathrm{CaCO}_{3}(\mathrm{~s}) \\
& \mathrm{CaCO}_{3}(\mathrm{l}) \rightarrow \mathrm{Ca}(\mathrm{OH})_{2}(\mathrm{~s})+\mathrm{CO}_{2}
\end{aligned}
$$

The process described in [19] can be used for commercial exploitation as through this process certain properties required for the different applications of silica can be obtained by tuning the operating parameters. The experiment work involved studying the quantity and quality of silica produced, although its quality largely depends on the precipitation conditions. Silica extracted from ash increases with temperature rise and also marginally dependent on the concentration of caustic.

\section{Product Utilization PlanNing}

\section{A. Electricity Utilization}

Irrespective of the location of the plant, demand for electricity is always towering in Bangladesh. Off-grid citizens, small enterprises and irrigation facilities might be the major consumer of generated electricity.

1) Rice Mills

It is financially viable to establish the plant near the area where a large amount of rice mills reside. Also rice mills in the locality can be the most potential customers of electricity. That minimizes both transportation cost of raw materials and distribution cost of electricity as potential clients like rice mills are available nearby. Except for a few, most of the rice mills operate for 7-8 months a year. Average power requirement of the rice mills is about $30 \mathrm{hp}(22.4 \mathrm{~kW})$. Per unit electricity cost from Rural Electrification Board (REB) and Power Development Board (PDB) is BDT 5.00. In context to current energy supply trend, load shedding is likely to have major influence over the profit of the rice mills. So they will be more than happy to have a continuous supply of electricity.

\section{2) Water supply for Irrigation}

Due to the power constraint, our potential in agricultural yield has never been attained fully. Irrigation in winter and dry season has been a wary for government for a long time. Electricity for irrigation has two-fold benefits as it will not only contribute to higher yield but also generate job opportunity. A small generation of 300-kW electricity can run thirty 2-cusec pumps, each with $10-\mathrm{kW} /$ per hour electricity consumption; can draw 7200cft water from underground. Initiatives like solar pump irrigation are taken as pilot with little success because of the primary cost involved that raises the question of affordability for marginalized farmers. Biomass based electricity generation doesn't impose that huge amount of investment on the farmers. Unlike other customers they just have to pay for the amount of electricity they use for irrigation.

\section{3) Rural dwellers}

Electricity demand in rural off-grid areas of Bangladesh is immense. Solar home system is holding the established position at lightning rural households. But due to high primary instalment and replacement cost of batteries, only better-off families can afford to have one. But a mini-grid based on rice husk biogas plant has benefits of flexibility in payment at the household level.

It is expected that the rural people will be able to get electricity at almost same price as conventional price provided by the government. Household demand analysis can give a distinct idea of total demand for the community.

\section{B. By-product Utilization}

Rice husk based biomass plant will generate significant amount of silica and calcium carbonate as by-product.

\section{1) Silica}

Silica has a huge demand in industries like rubber, tooth paste and other chemical industries. Given the fact that the entire domestic demand is met through import, such projects can initially substitute import by supplying silica and later on can export abroad. The sale price can be kept under current import price (BDT 100-120 per kg. including duties \& taxes; quotation enclosed) as production cost would be much less. Other applications for tailor made precipitated silica are to meet various requirements in cosmetics, tooth pastes as a cleansing agent and food industry as an anti-caking agent.

\section{2) Calcium Carbonate}

Calcium carbonate is mainly used in construction industry. It may be used as a building material, limestone aggregate for road building, ingredient of cement etc. For sale, BDT 10 per $\mathrm{kg}$ of calcium carbonate will be competitive based on the current market.

\section{BenEFITS OF THE PROPOSED METHOD}

In some of the smaller milling operations, the rice hulls generated are usually returned to the grower along with milled rice. Small growers use some of the rice hulls as animal feed or for bedding. Unless the rice husks contain the bran and a substantial amount of broken kernels of rice and rice powder (wasteful), the husks have little nutritional value. High silica content of the rice hulls severely limits the quantity that can be used in animal feed. Even moderate levels irritate the stomach lining and lead to weight loss in the animal.

Rice hulls contain about 20\% silica and are extremely slow to degrade. Rice hull piles present two health hazards. They become a food supply for rats, and second they trap water which acts as a breeding ground for mosquitoes, other insects and pests. In addition, the land used to store the rice hulls becomes temporarily sterile [20].

The proposed gasification process, contribute to the sustainable development through the effective utilization of surplus biomass residues available in the project region for power generation. There is almost no or very little GHG emission from this proposed method. Combustion of biomass in the project does not result in net increase in GHG emissions of $\mathrm{CO}_{2}, \mathrm{CH}_{4}$ and $\mathrm{NO}_{\mathrm{x}}$. Moreover, the decentralized power generation through biomass gasification will reduce the transmission and distribution losses. The project is using biomass for power generation. None the less, it shall create new rural income generation options and increased income shall contribute to the economic security and empowerment of the most vulnerable sections of the society.

Because of these multi-faceted attributes, electricity generation by gasification and production of precipitated 
silica and calcium carbonate is an elegant practice than conventional rice husk usage.

\section{CONSTRAINT TO DISSEMINATION OF NEW TECHNOLOGY}

\section{A. Recognition}

The recognition of technological improvement is influenced by its extent of compliance to specified safety, environmental and technical standards. Hence, official recognition of newer technology like rice husk gasification will be constrained as there is no base on which to judge the compliance of the improved technology.

\section{B. Structure of Policy and Regulation}

Complex structure of policy and regulation through several departments for prior approval hinders new technology to flourish. Moreover, in current government structure, no mechanism has been developed yet to judge and promote CDM projects. Thus unconventional technology like biogas gasification doesn't attract many investors.

\section{Attitudinal Barriers to shift}

There is a psychological barrier to shift from conventional system to the improved system. A psychological perception of the users on certain concepts of the conventional technologies may take time to change. The lack of awareness and low levels of education/technical knowledge is an added factor for shifting to new system.

\section{Available Loan facility}

Rice mills don't fall under the category of 'Small Industries' mainly because of its rural location and technological scheme. Thus subsidized credit for capital investment available to the owners of rice mills is unlikely. To draw attraction to the private investors the project should be profitable in short time. So, unless enough private investors are convinced that the technology is worth a try, unavailability of loan remains a major constraint to flourish this new technology.

\section{E. Raw material availability}

Major portion of rice husk is burnt for rice parboiling with primitive system, densification/briquetting etc. Raw material availability is also a concern for larger plants. Other than 4 distinct cluster areas for rice mills in Bangladesh, it will be difficult to keep the continuous supply to the plant [5]. Other alternatives could be used to fill up the deficit of rice husk, but that will increase the operation and transportation cost.

\section{CONCLUSION}

Rice is the major crop of Bangladesh and will remain that way for years to come; thus future supply of husk is protected. As these plants will be located in rural areas; they expected to generate direct and indirect skilled and unskilled employment/jobs in rural areas.

The biomass gasification technology is an alternative to fossil fuel based power plant and as it is decentralized, transmission and distribution losses of power will be low. Combustion of biomass through this process does not result in net increase in GHG emission of $\mathrm{CO}_{2}, \mathrm{CH}_{4}$ and $\mathrm{NO}_{\mathrm{x}}$. The process of generating electricity using gasification will ensure efficient and environment friendly utilization of rice husk. Moreover, this will also produce a high value by-product such as precipitated silica and calcium carbonate.
Therefore, apart from generating power from renewable sources, this method is also expected to save the country's hard earned foreign currency.

\section{REFERENCES}

[1] M. Rofiqul Islam, M. Rabiul Islam and M. Rafiqul Alam Beg, "Renewable energy resources and technologies practice in Bangladesh”, Renewable and Sustainable Energy Reviews (2006), doi:10.1016/j.rser.2006.07.003

[2] S.K. Patra and P.P. Datta, Technical Digest, Insights into Biogass Gasification Technology

[3] J. Waewsak, M. Mani, P. Buaphet and P. Panichayunon, “A Biomass Gas Engine System for Power Generation of OTOP Building in Southern Thailand”, Renewable Energy System Research and Demonstration Center (RERD), Department of Physics, Faculty of Science, Thaksin University, Thailand

[4] http://www.scribd.com/doc/51229514/GASIFICATION

[5] M. Ahiduzzaman. "Rice Husk Energy Technologies in Bangladesh" Agricultural Engineering International: the CIGR Ejournal. Invited Overview No. 1. Vol. IX. January, 2007.

[6] Dasgupta, N., Baqui, M. A., Dhingra S., Raman, P., Ahiduzzaman, M. And Kishore, V.V. N., Benefits of Improved Rice Husk Combustion, Bangladesh. NRI report no. 2764. p. 8, 21, 67, 2003

[7] APCTT-UNESCAP, Bangladesh Renewable Energy Report

[8] T.B Reed and A .Das, Handbook of biomass downdraft gasifier engine systems, The Biomass Energy foundation Press, Colorado, O.K.

[9] Hobbs, M.L., Radulovic, P.T., Smoot, L.D., Combustion and gasification of coals in fixed-beds. Energy Combustion Science, 1993

[10] Salo, K., Jartunen, M., Asplund, D., Production of Fuel with Gasification of Peat in Fixed Bed, Peat as an Energy Alternative Arlington, Virginia, December 1-3, 1980

[11] Arthur Okuga, "Analysis and operability optimization of an updraft gasifier unit”, M.S Thesis, Dept. Mech. Engineering, Eindhoven University of Technology, Eindhoven, Netherland s

[12] Jeng-Chyan .M.Lin, Combination of a Biomass Fired Updraft Gasifier and a Sterling Engine for Power Production, Journal of Energy Resources Technology, Volume 129, Issue 1, March, 2007.

[13] Activities in Bangladesh. Proceedings of Training Workshop on Renewable Energy Education and Application for Rural Communities in Bangladesh, Center for Energy Studies, Bangladesh University of Engineering and Technology, Dhaka, Bangladesh. pp. 368-379, Nov.27-Dec.03, 1999

[14] Buljit Buragohain, Pinakeswar Mahanta and Vijayanand S. Moholkar, Investigations in gasification of biomass mixtures using thermodynamic equilibrium and semi-equilibrium models, International Journal of Energy and Environment, Volume 2, Issue 3, pp.551-578, 2011

[15] Channiwala S.A., Parikh P.P. A unified correlation for estimating HHV of solid, liquid and gaseous fuels. Fuel 2002, 81, 1051-1063.

[16] Friedl A., Padouvas E., Rotter H., Varmuza K. Prediction of heating values of biomass fuel from elemental composition. Anal. Chim. Acta 2005, 544,191-198.

[17] U. Kalapathy, A. Proctor \& J. Shultz, An improved method for production of silica from rice hull ash, Bioresource Technology 85 (2002) 285-289

[18] CGPL, Indian Institute of Science, "Precipitated Silica from Rice Husk Ash”, India. Available: http://cgpl.iisc.ernet.in/site/Portals/0/Technologies/PrecipitatedSilica. pdf

[19] D.N. Subbukrishna, K.C. Suresh, P.J. Paul, S. Dasappa, N.K.S. Rajan, Precipitated Silica From Rice Husk Ash by IPSIT Process, $15^{\text {th }}$ European Biomass Conference \& Exhibition, Berlin, Germany, 7-11 May, 2007

[20] Schaffer \& Associates International, "Rice Husk to Energy: A Preliminary Assessment for the Republic of Mali”, USA, 2005

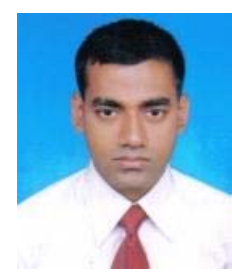

Arif Md. Waliullah Bhuiyan was born on 1986 in Mymensingh, Bangladesh. He completed his Bachelor of Science form Islamic University of Technology (IUT) in Electrical and Electronic Engineering (EEE) in 2008. Currently he is working in Disaster, Environment \& Climate Change (DECC) Programme of BRAC, the largest non-government organization in the world. Due to his nature of work, he has visited the remotest places of Bangladesh and developed a good insight about appropriate power solution to these places. 
He works on disaster risk reduction, environmental degradation and different climate change issues through innovative newer suitable technologies for Bangladesh. His research interests include renewable and smart grid technologies, control system and micro issues of climate change. He is a member of IACSIT. He has published various research works in several international journals and conferences. Email: bhuiyan.waliullah@gmail.com

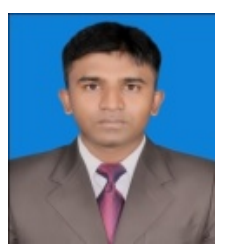

Md. Rejwanur Rashid Mojumdar was born in Dhaka, Bangladesh in 1986. He received his Bachelor of Science in Electrical and Electronic Engineering (EEE) from the Islamic University of Technology (IUT), Bangladesh in November 2008. Since April 2009 to April 2011, he had been working as site engineer at NLDC (National Load Dispatch Centre) Project of AREVA T\&D Bangladesh. It was a Supervisory Control and Data Acquisition (SCADA) deployment project to bring the National Power Transmission Substations (230/132/33 KV) under a central SCADA system and build the NLDC. Necessarily, he had visited almost all of the Transmission Sub-stations and Power Stations in Bangladesh and skillfully served some imperative responsibilities. Currently he is working as energy auditor of HM Enviro Care in ESIP (Energy Saving Initiative Project) on the Program of PSES (Promotion of Social, Environmental and Production Standards in the Industry) with cooperation of Deutsche Gesellschaft für Internationale Zusammenarbeit (GIZ) GmbH. Now, he is doing investment grade energy auditing for industries in
Bangladesh. Besides, he has very diverse research interests including renewable energy, control systems, SCADA systems and smart grid technologies. He has several published international journal and conference papers on various fields of Engineering. He is a member of IACSIT. E-mail: md.rejwanur.rashid.mojumdar@gmail.com

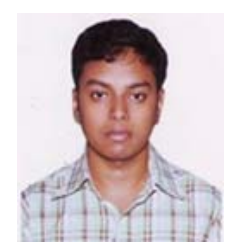

A K M Kamrul Hasan was born in Gaibandha, Bangladesh in $15^{\text {th }}$ December, 1989. He is on the verge of completing B.Sc. in Electrical and Electronic Engineering from the Islamic University of Technology (IUT), a subsidiary organ of OIC (Organization of Islamic Conference), Bangladesh on upcoming October 2011. He has accomplished four days training in INST (Institute of Nuclear Science and Technology), IE (Institute of Electronics), BAEC (Bangladesh Atomic Energy Commission) and visited to various laboratories and Nuclear reactor TRIGA MK II recently. He has also completed six days training in GPS (Ghorasal Power Station), BPDB (Bangladesh Power Development Board), Palash,Narsingdi and visited to Unit 1, 2 producing maximum of 55MW and Unit 3,4,5,6 producing maximum of 210MW. He has attained a training session in Satellite and Microwave station of BTCL, Korail,Bonani,Dhaka. Besides, he has various research interests including Smart Grid Technologies, Renewable energy, Control System Engineering, Bio medical Engineering and Microwave Engineering. E-mail: kamrul_2075@yahoo.com 